\title{
Female Genital Mutilation and Associated Factors in GonchaSiso-Enessie District, East Gojjam Zone, Amhara Region, Ethiopia (2012)
}

\section{Andualem $\mathbf{M}^{*}$}

Instructor at University of Gondar, Department of Health Informatics, Institute of Public Health, Gondar, Ethiopia

\begin{abstract}
Background: Female genital mutilation/cutting is the partial or total removal of the femaleexternal genitalia for various reasons using different cutting materials. It is estimated that more than 130 million girls and women alive today had undergone Female genital cutting, primarily in Africa and to a lesser extent in the Middle East. The prevalence of female genital cutting practices in Ethiopia is $74.3 \%$ and in Amhara region, it is $68.5 \%$.

Methods: A cross sectional study using both quantitative and qualitative approaches wasconducted to assess the prevalence and associated factors for female genital cutting. Pretested structured self-administered questionnaire and interview guidelines were used to collect the required data on different variables. Bivariate and multivariate logistic regression analyses were used to identify then determinants of female genital cutting. Strength of the association was assessed using odds ratio with 95\% Confidence Level.

Results: A total of 730 mothers with the mean Standard Deviation age of $29 \pm 7$ standarddeviation were participated in the study. The prevalence of Female genital cutting was higher, $62.7 \%$ on under five daughters in the study area. Health education (AOR=0.19; 95\%, $\mathrm{Cl}=0.08-0.45)$, age $15-24$ years $[\mathrm{AOR}(95 \% \mathrm{Cl})=0.20(0.06-0.64)]$, women's educational status

[AOR $(95 \% \mathrm{Cl})=5.43(1.88,55.68)]$, women themselves circumcised [AOR $(95 \% \mathrm{Cl})=3.45(1.35,8.79)]$ and criminal [AOR $(95 \% \mathrm{Cl})=0.37(0.16,0.86)]$ were found significantly associated with female genital cutting.

Conclusions: Female genital cutting was highly practiced among rural women than urban. Age,educational status, residence, being circumcised, health education, knowledge on female denial cutting and believing it as criminal were found to be determinants of female genital cutting.
\end{abstract}

Keywords: Female genital cutting; Traditional birth attendances; Values; Beliefs; Ethiopia

\section{Background}

Female genital mutilation (FGM/C), or female circumcision, includes all procedures involving partial or total removal of the external female genitalia or other injuries to the female genital organs whether for cultural or other non-therapeutic reasons [1,2]. There are four main types of FGM/Cs: Type 1: Clitoridectomy/Sunna involves the removal of the clitoral hood with or without removal of all or part of the clitoris. Type 2: excision varies from the removal of the clitoris and/ or clitoral prepuce to the removal of part or the entire clitoris together with part or all of the labia minora (the inner vaginal lips). Type 3: infibulation involves the removal of the clitoris, the labia minora, and part of the labia majora after which the edges of the wound are sutured to leave a small opening (vaginal orifice). Type 4: unclassified and the intermediate practice refers to the amputation of the clitoris and parts of the labia minora [2-4].

The health consequences vary according to the type and severity of the procedure performed. The immediate complications include severe pain, shock, hemorrhage, urine retention, and injury to adjacent tissue or death. Long-term consequences include urinary incontinence, painful sexual intercourse, sexual dysfunction, difficulties with childbirth, scaring and infertility [3].

Worldwide, between 100 and 140 million girls and women had experienced FGM/C. It is estimated that at least 2 million girls are at risk from FGM/C every year. Type1 and two are the most common forms of FGM/C; $80 \%$ of cases and infibulations accounted for $15 \%$ of cases [2,5]. Most women and girls with FGM/C lived in 28 sub-Saharan African countries with few figures from Asia and the Middle East. Due to the migration of people who practiced this tradition, FGM/C is today evident in Australia, Canada, the United States and the European Union [4]. The prevalence of FGM/C varied from nation to nation such as Niger (5\%), Ghana (5\%), Benin (17\%), United Republic of Tanzania (18\%), Nigeria (19\%), Eritrea (89\%), Sudan (90\%), Egypt (97\%) and Ethiopia (80\%) [4,6-10].

According to Demographic and Health Survey report of Ethiopia, $74 \%$ of girls and women nationwide had subjected to FGM/C. The Regional distribution of FGM/C prevalence was: $91.6 \%$ in Afar, $85.1 \%$ in Harare, $68.5 \%$ in Amhara, $87.2 \%$ in Oromia, $65.7 \%$ in Addis Ababa, $97.3 \%$ in Somali, $67.6 \%$ in BenishangulGumuz, $29.3 \%$ in Tigray, $27.1 \%$ in Southern and $92.3 \%$ in Dire Dawa Region [11]. The most responsible identified factors for practicing FGM/C were believes, religion, education, and tradition, gender-related factors, health and Socio-economic factors $[12,13]$.

\section{Methods}

A community based cross sectional study was conducted using

*Corresponding author: Andualem M, Instructor at University of Gondar, Department of Health Informatics, Institute of Public Health, Gondar, Ethiopia, Tel: 251-913814608; E-mail: muler.hi@gmail.com

Received December 02, 2013; Accepted December 23, 2013; Published December 30, 2013

Citation: Andualem M (2013) Female Genital Mutilation and Associated Factors in GonchaSiso-Enessie District, East Gojjam Zone, Amhara Region, Ethiopia (2012). J Health Med Informat 4: 141. doi:10.4172/2157-7420.1000141

Copyright: (c) 2013 Andualem M. This is an open-access article distributed under the terms of the Creative Commons Attribution License, which permits unrestricted use, distribution, and reproduction in any medium, provided the original author and source are credited. 
Citation: Andualem M (2013) Female Genital Mutilation and Associated Factors in GonchaSiso-Enessie District, East Gojjam Zone, Amhara Region, Ethiopia (2012). J Health Med Informat 4: 142. doi:10.4172/2157-7420.1000142

Page 2 of 5

both quantitative and qualitative methods to assess the prevalence and determinant factors of FGM/C at GonchaSiso-Enessie district, East Gojjam, Western Ethiopia, 2013. The district is located about $345 \mathrm{Kms}$ from Addis Ababa city and $153 \mathrm{Kms}$ from Bahir Dar town; a capital city of Amhara Region. It has an area of $2,500.85 \mathrm{~km}^{2}$ and had an estimated total population of 141,068 (71,240 male and 69,829 female). Its $95 \%$ population is living in rural areas and Agriculture is the backbone of its economy. The district has a total of 28 functioning health institutions ( 6 health centres and 22 health posts).

The study population were all women in reproductive age group (15-49) residing in the District who had daughter less than five years old. The sample size was calculated using single proportion formula by considering the following assumptions: $95 \% \mathrm{CI}$, prevalence of region is $68.5 \%$, variation as $5 \%, 10 \%$ contingency and design effect 2 . Five kebeles in the district were selected randomly and households from each selected kebeles were also selected randomly to select 730 participants. Then, women from randomly selected houses were interviewed until the total sample is attained.

Quantitative data were collected via interviewing using pretested and structured questionnaire. The questionnaire was prepared in English, translated to Amharic and then translated back to English to check for consistency. Seven health care workers and two supervisors were participated in the data collection. One day training was given to data collectors and supervisors about the objective, relevance of the study, confidentiality of information, participant's right, pre-test, informed consent and techniques of interview. Qualitative data were collected through Focus Group Discussion (FGD) using unstructured interviewing guidelines and tape recorder after getting consent from participants. The principal investigator conducted FGD among 23 women assumed to be key informants until reaching to the saturation with 3 groups consisting of eight women.

Two supervisors and the principal investigator made frequent checks on the data collection process to ensure the completeness and consistency of the gathered data. Data were cleaned manually, entered and cleaned using EPI info version 6 and exported to SPSS version 20 for further cleaning and analysis. Frequencies, cross tabulation, binary and multivariate analysis were done to see presence of association between dependant and independent variables. Odds ratio and confidence intervals were used to describe observed associations among variables.

\section{Results}

\section{Socio demographic characteristics of the participants}

A total of 730 mothers with the mean age of $29( \pm 7)$ years were included in the analysis. Majority of women; 710 (97.3\%) were Amhara and the rest were Tigrie and Oromo. Most of the study participants; $705(96.6 \%)$ were identified as orthodox and the left $25(3.4 \%)$ were Muslim and other Christianity followers. Of 730 respondents, $87.7 \%$, $67.3 \%$ and $18.9 \%$ were married, cannot read-write and primary school and above respectively. Only $13(1.8 \%)$ respondents were employees and 343 (43\%) had monthly income ranging from 556-1233 Ethiopian Birr (ETB). In case of qualitative study, only four of 23 had completed their primary school education. All, except three had husbands and all were farmers and orthodox followers (Table 1).

\section{Female genital mutilation/cutting (FGM/C) practices}

Of the total 730 women, 567 (77.7\%) were genitally circumcised and $458(62.7 \%)$ of their daughters were genitally circumcised. This

\begin{tabular}{|c|c|}
\hline Variables & Frequency (\%) \\
\hline \multicolumn{2}{|l|}{ Age in years: } \\
\hline 15---24 & $198(27.1)$ \\
\hline 25---34 & $338(46.3)$ \\
\hline 35---49 & $194(26.6)$ \\
\hline \multicolumn{2}{|l|}{ Religion: } \\
\hline Orthodox & 705 (96.6) \\
\hline Others & $25(3.4)$ \\
\hline \multicolumn{2}{|l|}{ Marital status: } \\
\hline Single & $18(2.5)$ \\
\hline Married & $640(87.7)$ \\
\hline Divorced & $68(9.3)$ \\
\hline Widowed & $4(0.5)$ \\
\hline \multicolumn{2}{|l|}{ Ethnicity: } \\
\hline Amhara & $710(97.3)$ \\
\hline Others & $20(2.7)$ \\
\hline \multicolumn{2}{|l|}{ Educational status: } \\
\hline Can't read and write & $491(67.3)$ \\
\hline Read -write & $101(13.8)$ \\
\hline Primary school (1-8 and above) & $138(18.9)$ \\
\hline \multicolumn{2}{|l|}{ Occupation: } \\
\hline Farmer & $710(97.3)$ \\
\hline Others & $20(2.8)$ \\
\hline \multicolumn{2}{|l|}{ Income per month: } \\
\hline Less than 555 birr & $258(35.3)$ \\
\hline $556-1233$ birr & $343(47)$ \\
\hline More than 1233 birr & $125(17.1)$ \\
\hline Unknown & $4(0.5)$ \\
\hline \multicolumn{2}{|l|}{ Family size: } \\
\hline One to two & $33(4.5)$ \\
\hline Three to four & $383(52.5)$ \\
\hline Five to six & $187(25.6)$ \\
\hline Seven and above & $127(17.4)$ \\
\hline
\end{tabular}

Table 1: Socio-demographic characteristics of respondents in Goncha SisoEnessie District, Ethiopia, $2012(\mathrm{~N}=730)$.

finding was in agreement with qualitative result where majority of women themselves and their under-five daughters were circumcised.

Of the total 458 circumcised daughters, 439 (95.9\%) were under one year old, 18 (3.9\%) were from 1-2 years old and only one was 3-4 years old. This circumcision age was also true in qualitative result. Majority, $380(83 \%)$ were circumcised by traditional circumcisers and the rest 78 (17\%) were circumcised by traditional birth attendant (TBA). Majority, $411(89.7 \%)$ were circumcised by their own blade and the rest 47 (10.2\%) were circumcised by shared blade, but in case of FGD, almost all participants agreed as they used own blade for circumcision purpose. One 21years respondent said, "I did not use shared blade, because it is the cause for HIV/AIDs". From the total circumcised daughters, 444 (96.9\%) circumcised at their own home, $11(2.4 \%)$ at others' home and the rest $3(.7 \%)$ were circumcised at circumcisers' home. This was also true in qualitative study.

In general, of the 730 respondents, 455 (62.9\%) of women did not know that FGC was associated with health problems. Similarly, majority of respondents in qualitative study did not know whether FGM/C resulted in health problems on circumcised groups. More than half, $449(61.5 \%)$ of respondents supported the continuation of FGM/C practice by mentioning some reasons like to get acceptance within community, to respect values/traditions, to get husband easily, to be free from taboo, etc (Table 2). Majority of qualitative respondents agreed on this idea and mentioned reasons in their discussion: one 
Citation: Andualem M (2013) Female Genital Mutilation and Associated Factors in GonchaSiso-Enessie District, East Gojjam Zone, Amhara Region, Ethiopia (2012). J Health Med Informat 4: 142. doi:10.4172/2157-7420.1000142

Page 3 of 5

\begin{tabular}{|c|c|}
\hline Variables & Frequency (\%) \\
\hline \multicolumn{2}{|c|}{ FGC caused the health problems $(730)$ : } \\
\hline Yes & $\begin{array}{c}275 \\
(37.3)\end{array}$ \\
\hline No & $\begin{array}{c}455 \\
(62.3)\end{array}$ \\
\hline \multicolumn{2}{|c|}{ Supported the continuation of FGM/C (730): } \\
\hline Yes & $\begin{array}{c}449 \\
(61.5)\end{array}$ \\
\hline No & $\begin{array}{c}282 \\
(38.6)\end{array}$ \\
\hline \multicolumn{2}{|c|}{ Not supported continuation of FGM/C (282): } \\
\hline Religious prohibition & $\begin{array}{c}40 \\
(5.5)\end{array}$ \\
\hline Sexual dissatisfaction & $\begin{array}{c}31 \\
(4.2)\end{array}$ \\
\hline Medical complication & $\begin{array}{c}202 \\
(27.7)\end{array}$ \\
\hline Painful personal experience & $\begin{array}{c}5 \\
(0.7)\end{array}$ \\
\hline Rights/woman's dignity & $\begin{array}{c}4 \\
(0.5)\end{array}$ \\
\hline \multicolumn{2}{|c|}{ Husband's opinion on continuation of FGM/C (730): } \\
\hline Favours & $\begin{array}{c}383 \\
(52.5)\end{array}$ \\
\hline Opposes & $\begin{array}{c}257 \\
(12.3)\end{array}$ \\
\hline No opinion & $\begin{array}{c}90 \\
(12.3)\end{array}$ \\
\hline \multicolumn{2}{|l|}{ Health education (730): } \\
\hline Yes & $\begin{array}{c}264 \\
(36.2)\end{array}$ \\
\hline No & $\begin{array}{c}466 \\
(63.8)\end{array}$ \\
\hline
\end{tabular}

Table 2: Respondents' knowhowand proposed solutions for FGM/C in Goncha Siso-Enessie.

30 years woman said that, "If female genital cutting didn't take place, women could be suffered from illness and many difficulties". According to her explanation, "a woman from their neighbourgot suffered from difficulties during delivery for two days because of absence of female circumcision".

However, few were against to FGM/C practice; for example, one 23 years old participant in FGD said "I saw previously women who were circumcised and non-circumcised, but gave birthwithout any problems, so the reasons were bad traditions came from ancestors called AbatAder" (local language to mean it is culture or value).

Regarding to health education access to the respondents, 264 (36.2\%) and $466(63.8 \%)$ respondents got and did not get health education from any source respectively. About $516(70.7 \%)$ respondents agreed that FGM/C is not violation of human rights/criminal (Table 3). Concerning decision makers on FGM/C in households, all family members were participated inDoing decisions on their daughters, except daughters themselves. Majority of decisions; $72.5 \%$ Were passed by mothers, $16.2 \%$ by fathers, $8.7 \%$ by grandmothers and $2.6 \%$ were made by grandfathers. Some of the mentioned reasons by both quantitative and qualitative respondents why communities practiced FGM/C in the study area were: tradition/custom, simple to give births, simple to disverge, it is value, it increases happiness during sex, it increases society acceptance,easy to get husband and gives society respection to their families (Figure 1). For example, one 35 years old woman raised that; "FGM/C should be practiced because ithelps women to be respected by the society, unless she is blamed by the community so called Difin Qil or Woshela/Qintiram", which is a local word/name given to none circumcised women.

\section{Factors associated with $\mathrm{FDM} / \mathrm{C}$ in reproductive age group women}

According to binary and multivariate logistic regression analysis of this study, women's age, educational level, previous circumcision, FGC knowhow, health education and women's opinion on EGC as criminal

\begin{tabular}{|c|c|c|c|c|}
\hline \multirow[t]{3}{*}{ Variables } & \multicolumn{2}{|c|}{ Circumcised } & \multirow{2}{*}{\begin{tabular}{|l|} 
Crude OR \\
$(95 \% \mathrm{Cl})$ \\
\end{tabular}} & \multirow{2}{*}{\begin{tabular}{|l|} 
Adjusted OR \\
$(95 \% \mathrm{Cl})$
\end{tabular}} \\
\hline & \multicolumn{2}{|c|}{ Daughters $<5 \mathrm{yrs}$} & & \\
\hline & Yes & No & & \\
\hline \multicolumn{5}{|l|}{ Age in years: } \\
\hline 15---24 & 80 & 118 & $0.13(0.08-0.20)$ & $0.20(0.06-0.64)$ \\
\hline 25---34 & 215 & 123 & $0.32(0.21-0.50)$ & $0.52(0.17-1.45)$ \\
\hline $35---49$ & 163 & 31 & 1.00 & 1.00 \\
\hline \multicolumn{5}{|l|}{ Women religion: } \\
\hline Orthodox & 435 & 270 & $0.14(0.02-0.62)$ & $0.57(0.04-8.27)$ \\
\hline Others & 23 & 2 & 1.00 & 1.00 \\
\hline \multicolumn{5}{|l|}{ Ethnicity: } \\
\hline Amhara & 450 & 260 & $2.60(0.97-7.05)$ & $0.69(0.05-8.84)$ \\
\hline Others & 8 & 12 & 1.00 & 1.00 \\
\hline \multicolumn{5}{|l|}{ Marital Status: } \\
\hline Single & 11 & 7 & $1.57(0.18-13.86$ & $17.24(0.20-1.50)$ \\
\hline Married & 403 & 237 & $1.70(0.24-12.15)$ & $10.96(0.28-431.06)$ \\
\hline Divorced & 42 & 26 & $1.62(0.21-12.18)$ & $4.24(0.086-208.11)$ \\
\hline Widowed & 2 & 2 & 1.00 & 1.00 \\
\hline \multicolumn{5}{|l|}{ Educational status: } \\
\hline Cannot read/write & 383 & 109 & $28.37(16.14-49.89)$ & $5.43(1.88-15.68)$ \\
\hline Read/write & 38 & 62 & $9.12(4.75-17.50)$ & $3.10(0.88-10.97)$ \\
\hline Primary (1-8) \& above & 37 & 101 & 1.00 & 1.00 \\
\hline \multicolumn{5}{|c|}{ Occupation: } \\
\hline Farmers & 453 & 257 & $5.29(1.78-16.84)$ & $0.34(0.03-4.12)$ \\
\hline Others & 5 & 15 & 1.00 & 1.00 \\
\hline \multicolumn{5}{|l|}{ Income: } \\
\hline Less than555 Birr & 166 & 92 & $5.41(0.56-52.79)$ & $7.27(0.04-4.55)$ \\
\hline 556-1233 Birr & 209 & 134 & $4.68(0.48-45.45)$ & $4.56(0.05-2.84)$ \\
\hline More than 1233 Birr & 82 & 43 & $5.72(0.58-56.67)$ & $7.08(0.02-4.50)$ \\
\hline Unknown & 1 & 3 & 1.00 & 1.00 \\
\hline \multicolumn{5}{|l|}{ Women circumcision: } \\
\hline Yes & 379 & 192 & $2.00(1.38-2.90)$ & 3.45 (1.35-8.79) \\
\hline No & 79 & 80 & 1.00 & 1.00 \\
\hline \multicolumn{5}{|l|}{$\begin{array}{l}\text { Knew FGC cause health } \\
\text { problems: }\end{array}$} \\
\hline Yes & 42 & 233 & $0.02(0.01-.03)$ & $0.01(0.005-.04)$ \\
\hline No & 416 & 38 & 1.00 & 1.00 \\
\hline \multicolumn{5}{|l|}{ Ways to eradicate FGC: } \\
\hline Enforced legislation & 45 & 209 & $0.04(0.02-0.10)$ & $0.03(0.003-0.31)$ \\
\hline Educational campaign & 379 & 57 & $1.17(0.47-2.92)$ & \\
\hline $\begin{array}{l}\text { Improvement of women } \\
\text { status }\end{array}$ & 34 & 6 & 1.00 & 1.00 \\
\hline \multicolumn{5}{|l|}{ Health education: } \\
\hline Yes & 47 & 217 & $0.03(0.02-0.05)$ & $0.19(0.08-0.45)$ \\
\hline No & 411 & 55 & 1.00 & 1.00 \\
\hline \multicolumn{5}{|l|}{$\begin{array}{l}\text { Women Knew FGC as } \\
\text { criminal: }\end{array}$} \\
\hline Yes & 81 & 133 & $0.22(0.16-0.32)$ & $0.37(0.16-0.86)$ \\
\hline No & 377 & 139 & 1.00 & 1.00 \\
\hline
\end{tabular}

Table 3: Association between FGM/C and selected variables in Goncha SisoEnessie District, $2013(\mathbf{n}=\mathbf{7 3 0})$. 


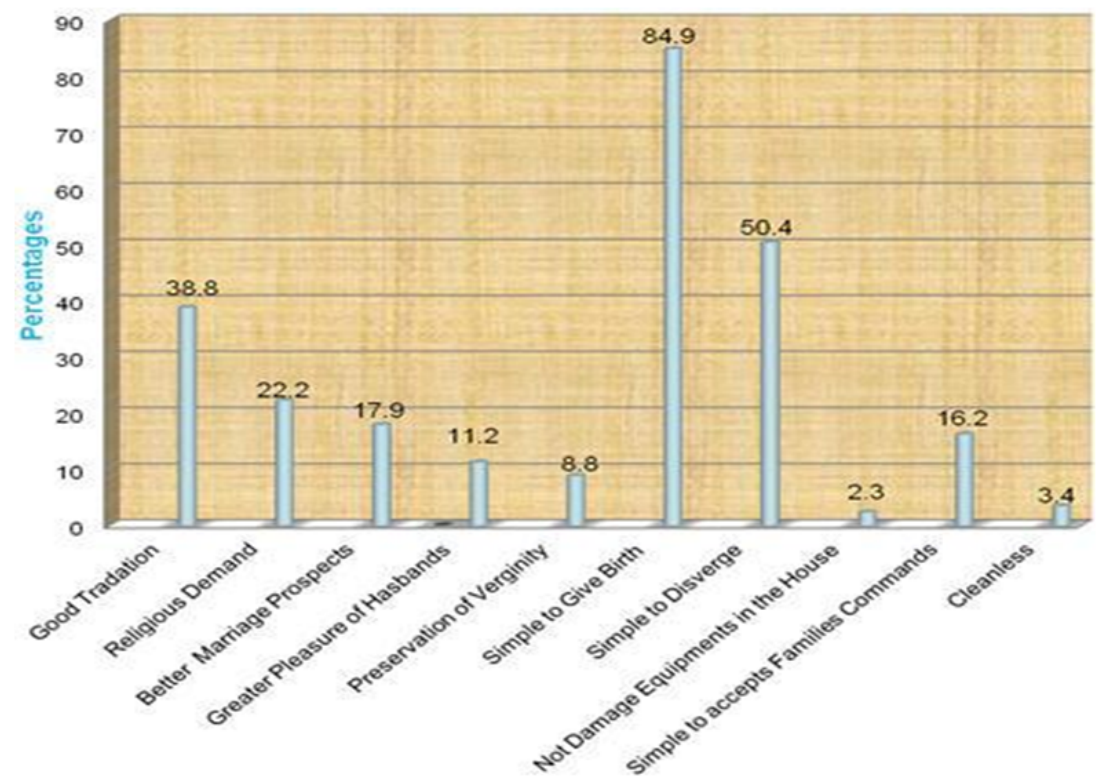

Figure 1: Main reasons for practicing FGM/C in Goncha Siso-Enessie District, East Gojjam, Ethiopia, 2013.

were significantly associated with FGM/C practices in the study area. Women with the age of 15-24 years were less likely to practiced FGM/C than those with age of 34-49 years [AOR (95\% CI) $=.20(.06-.64)$ ]. Women who did not attend school were 5.43 times practiced than who did formal school $[$ AOR $(95 \% \mathrm{CI})=5.43(1.88-15.68)]$.

Respondents who previously circumcised were 3.45 times practiced on their daughters compared with those none circumcised once [AOR $(95 \% \mathrm{CI})=3.45(1.35-8.79)]$. The participants who knew female circumcision can cause health problems and those who took health education on FGM/C were less likely to practice FGM/C than those who did not know and take health education [AOR $(95 \% \mathrm{CI})=.01$ $(.005-.04)]$ and $[$ AOR $(95 \% \mathrm{CI})=.19(.08-.45)]$, respectively.

The above result was in line with results obtained from qualitative study. For example, A 38 years old farmer women said; "Iffemale genital cutting didn't take place, women could besuffered from illness and many difficulties during delivery and sexual intercourse".

Majority of respondents from qualitative study did not take health education on FGC; thereby they did not know their country's law on traditional malpractices. Two respondents told that;

"FGC practice will not stop by this condition, unless there strong education on it and thenpunishment by the rule of law of a country".

Another participant also said that;

"There should be uninterrupted health education including law of the country on traditionalpractices within the community using different opportunities like Edir, Ekub, elders, kebeles leaders, health extension workers, religious leaders, female associations, and similar means".

\section{Discussion}

Even though FGM/C is a very deeply rooted harmful tradition practice which will result in several complicated health problems including loss of body parts within the community, it is preventable if there is a coordinated action on it at community level starting from awareness creation to punishing those who become ignorant to the program $[11,12,14-16]$.
Based on the current study findings, about more than half, $62.7 \%$ of study participants were circumcised at different levels of their age. This finding was lower when compared with study findings from Sudan where its practice was over $90 \%$ and in Egypt as its practicing rate was $95.7 \%[10,12,17]$. This figure was also slightly low as compared with findings of EDHS 2011 report, which was 68.5\% among 15-49 aged women for Amhara Region [11]. This may be due to the variation in study area and period, variation in efforts of health extension workers and timely increase to visit health institutions for other services. The presence of high of FGM/C in regional level is an indicator of the presence of other districts or zones with higher FGM/C prevalence than the current study area.

On the other hand, this figure was considerably higher than studies conducted in Burkina Faso [18] where FGC prevalence was 30.2\% and in Somali refugees in Ethiopia, which was only $30 \%$ of daughters aged below five years were circumcised [14]. This is most probably due to cultural variation, where FGM/C is less practiced in Somali region for various reasons like controlling method for girls from sexual activities unless they married and also due to respondents' age variation.

Educational status and age had shown statistically significant association with $\mathrm{FGM} / \mathrm{C}$ practices in the study. Individuals with educational status of primary and above were less likely practices than those who had no formal education. This finding is in line with other studies done in Ethiopia [15,19]. This might be due to individuals' exposure variation for information about FGM/C and its consequences. It is obvious that people at learning are more likely to get information on various issues than their counter parts.

In the study area, majority; $62.3 \%$ of respondents did not have knowledge on health related complications of FGM/C practices. From the above, $91.4 \%$ their daughters were circumcised, whereas $15.3 \%$ of daughters of none circumcised women were circumcised. The same study findings were observed from studies conducted in Sierra Leone [20], and in Northern Iraq [21] and in Kersa district, East Hararge, Ethiopia [15]. This is mainly due to knowledge variation on the topic among those who have exposure and their counter parts. However, the 
Citation: Andualem M (2013) Female Genital Mutilation and Associated Factors in GonchaSiso-Enessie District, East Gojjam Zone, Amhara Region, Ethiopia (2012). J Health Med Informat 4: 142. doi:10.4172/2157-7420.1000142

Page 5 of 5

most probable reason for being similar for two districts is that both are rural woredas and almost have similar infrastructures.

Traditional circumcisers and traditional birth attendants performed most circumcision activities in the study area. This finding was similar with other study findings in different regions and districts of Ethiopia $[14,15,22]$. The most logical reasons for performing circumcision by traditional way could be pushes from elders and circumcisionors, free of getting acceptance from health professionals, fear of operational free and transportation problems.

Respondents who took health education concerning FGM/C were poorly practiced the issue compared to the majority of their counter parts. This finding was in line with study findings conducted in Ethiopia and Egypt $[10,12,14,15]$. The most clear and probable reason for this may be knowledge gaps between the two comparative groups. It is clear that if someone knows something is harmful, its involvement in doing that activity will be less, but may not be still zero. Even though health education was the primary activity of health extension workers, majority of respondents did not get the service in the study area. This is the major identified gap and another possible reason for the presence of high prevalence of FGM/C practices there.

Even if $\mathrm{FGM} / \mathrm{C}$ practices were considered as criminals by the federal government, its implementation was not still on ground. Only few, 37.8\% respondents knew that FGM/C is criminal. It agreed with study findings from South Africa [23] where community awareness of law against harmful traditional practices. This was also another clear gap on disclosure and implementation of law from government and other concerned bodies. It would be one measure for giving emphasis on the issue among the community if it were done accordingly. Providing the right information to the right body at the right time and within the right means is the duty of governing body and the right of the community for doing their day-to-day activities without affecting their environment.

\section{Conclusions}

The results of this study showed that FGM/C is practiced at higher level; the determinants of FGM/C are mostly socio-demographic related. Women's age, education, previous circumcised, health education, enforced legislation, know how on FGM/C, opinion of circumcisionors, traditions and community values were the most identified significant factors for the presence of high FGM/C prevalence in the study area. Encouraging women to complete primary and above schools, providing uninterrupted integrated health education through elders, health extension workers, women affairs, youth associations and applying enforced legislation are important means to slowdown the prevalence and prevent FGM/C related health complications. Researchers should also explore effective ways of preventing FGM/C at regional and then nationwide level since it is a harmful tradition on human's body.

\section{Authors' Contributions}

The author Mulusew Andualem participated in all steps of the study from its commencement to write up, result dissemination, manuscript preparation and reviewing activities through the consultation of senior researchers and advisors.

\section{Acknowledgements}

I am very much grateful to acknowledge Goncha district administration, Cultural and Truism office, Office of women affairs and woreda health office for their financial, idea and all over supports. We wish to acknowledge supervisors, data collectors and study participants for their unreserved supports and collaborations throughout the project.

\section{References}

1. Leye E, Powell RA, Nienhuis G, Claeys P, Temmerman M (2006) Health Care in Europe for Women with Genital Mutilation. Health Care Women Int 27: 362 378

2. Sakeah E, Beke A, Doctor HV, Hodgson AV (2006) Males' preference for circumcised women in Northern Ghana. Afr J Reprod Health 10: 37-47.

3. Oduro AR, Koram KA (2006) Trends in the prevalence of female genital mutilation and its effect on delivery outcomes in the Kassena- Nankana District of Northern Ghana. Ghana MedicalJournal 40: 87-92.

4. Female Genital Cutting Harmful and Un-Islamic (2010). Wise Muslim Women's Shura Council. Female Genital Cutting: Harmful and Un-Islamic.

5. Monjok E, Essien EJ, Holmes L (2007) Female Genital Mutilation: Potentia for HIV Transmission in sub-Saharan Africa and Prospect for Epidemiologic Investigation and Intervention. Afr J Reprod Health 11: 33-42.

6. Nour NM (2008) Female Genital Cutting: A Persisting Practice. Rev ObstetGyneco I1: 135-139.

7. Population Reference Bureau. Female Genital Mutilation/Cutting (2010). Data and Trends Update.

8. Adriana Kaplan-Marcusán, NatividadFernández del Rio, Juana MorenoNavarro, Ma José Castany-Fàbregas, Marta Ruiz Nogueras, et al. (2010) Female Genital Mutilation: perceptions of healthcare professionals and the perspective of the migrant families. BMC Public Health 10: 193.

9. Kolawole, Kwaak A (2010) Review of determinants of female genital mutilation in Nigeria. Journal of Medicine and Medical Sciences 1: 510-515.

10. Emam EA, EL-Maghawri AM, Labeeb SA (2011) Cultural awareness about female genital mutilation among female employees of Minia University. Journal of American Science 7: 611-617.

11. Demographic and Health Survey. Journal of health survey Ethiopia (2005), FMOH CSA

12. Tag-Eldin MA, Gadallah MA, Al-Tayeb MN (2008) Prevalence of female genital cutting among Egyptian girls: Bulletin of the World Health Organization 86: 269274

13. Kandil M (2012) Female circumcision: Limiting the harm. F1000 Research.

14. Mitike G, Deressa W (2009) Prevalence and associated factors of female genital mutilation among Somali refugees in eastern Ethiopia: a cross-sectional study. BMC Public Health 9: 264.

15. Yirga WS, Kassa NA, Gebremichael MW, Aro AR (2012) Female genital mutilation: prevalence, perceptions and effect on women's health in Kersa district of Ethiopia. Int J Womens Health 4: 45-54.

16. Abdulcadira J, Margairazb C, Boulvaina M, Iriona O (2011) Swiss Med Wkly.

17. Bedri NM (2012) Ending FGM/C through Evidence Based Advocacy in Sudan.

18. Karmaker B, Kandala NB, Chung D, Clarke A (2011) Factors Associated with Female Genital Mutilation in Burkina Faso and its Policy Implications. Int $J$ Equity Health 10: 20

19. G Mariam A, Hailemariam A, Belachew T, Michael K, Lindstrom D (2009) Support for the continuation of female genital mutilation among adolescents in Jimma Zone, Southwest Ethiopia. Ethiop J Health Sci 19: 119-129.

20. Bjälkander O, Bangura L, Leigh B, Berggren V, Bergström S, et al. (2012 Health complications of female genital mutilation in Sierra Leone. International Journal ofWomen's Health 4: 321-331.

21. Kizilhan $\mathrm{Jl}$ (2011) Impact of psychological disorders after female genital mutilation among Kurdish girls in Northern Iraq. EurJ Psychiat 25: 92-100.

22. GonchaSiso-Enessie District children, youth and women annual report (2012), June.

23. Cantius J (2012) A South African Perspective on the Clash between Culture and Human rights, with particular reference to gender-related cultural practices and traditions. Journal ofInternational Woman's Studies 13: 34-48. 